\title{
Influence of Coffee Pruning on the Severity of Frost Damage
}

\author{
Armando Androcioli Filho* and Paulo Henrique Caramori \\ Scientific Researchers of Instituto Agronômico do Paraná - IAPAR, Caixa Postal 481, CEP 86001-970, Londrina - \\ PR, Brazil
}

\begin{abstract}
Frost damages in a field experiment of pruning types and systems for the cultivars of Coffea arabica Catuai and Mundo Novo, were evaluated at Londrina (23 $\left.22^{\prime} \mathrm{S}, 52^{\circ} 10^{\prime} \mathrm{W}\right)$, State of Parana, southern Brazil, during the winter of 1990 and 1994. Pruning types evaluated were 'esqueletamento' (cutting off all plagiotropic branches at 20-30 cm from the orthotropic branch), 'decote' (cutting off the orthotropic branch at $1.5 \mathrm{~m}$ and $2.0 \mathrm{~m}$ above ground) and 'recepa' (cutting off the orthotropic branch at $0.8 \mathrm{~m}$ above ground), performed on all rows and on alternate rows, and on different sections of the plant. Results indicated that frost damage could increase according to the type and height of pruning. The pruning type 'esqueletamento' and prunings at higher levels were more suitable for regions with frost risk. Under severe frost condition, pruning type did not affect the damage in anyone of the treatments evaluated.
\end{abstract}

Key words: pruning - Coffea arabica - coffee cultivars - frost

\section{INTRODUCTION}

The old coffee plantations of Parana State have been substituted according to recommendations for a new technological model of coffee production, based on high density planting (Instituto Agronômico do Paraná, 1991). This new way of cultivation requires the use of pruning to reduce competition among plants during the adult phase. Pruning modifies the architecture of coffee plants, with implications on the magnitude of frost damage if it occurs in the following winter.

Lethal temperature for coffee leaves in field conditions is between $-3^{\circ} \mathrm{C}$ and $-4^{\circ} \mathrm{C}$ (Camargo and Salati, 1967). Damages become more severe with the increase of exposition to critical temperatures (Manetti Filho and Caramori, 1986). Under typical radiative frosts, grass temperatures as low as $-7^{\circ} \mathrm{C}$ have been recorded in Londrina, while screen temperatures at $2 \mathrm{~m}$ height were between 0 and $2{ }^{\circ} \mathrm{C}$ (Caramori and Manetti Filho, 1993). This explains why young plants or those submitted to severe pruning may suffer more severe damages after a frost.
Frost damages may also vary with cultivar characteristics such as height, vigor, and production of coffee beans on the year with frost (Caramori and Sera, 1978, 1979; Siqueira et al., 1983; Androcioli Filho et al., 1986), plant nutrition (Chaves and Manetti Filho, 1990), and with the level of shade of the coffee plantation (Caramori et al., 1996).

The objective of this work was to evaluate damages caused by frost on coffee plants submitted to different types and systems of pruning.

\section{MATERIALS AND METHODS}

Frost damages were evaluated on the two cultivars of Coffea arabica Catuaí and Mundo Novo, with semi dwarf and tall growth habit, respectively, located at two nearby experimental fields in Londrina, PR, Brazil $\left(23^{\circ} 22^{\prime} \mathrm{S}\right.$ latitude, $51^{\circ} 10^{\prime} \mathrm{W}$ longitude, $585 \mathrm{~m}$ altitude). The soil at the site is classified as dusky-red dystrophic latosol (Faria and Caramori, 1986). Coffee was planted spaced $2.5 \mathrm{~m}$ between rows by $2.0 \mathrm{~m}$ in the row, with two plants per planting

\footnotetext{
* Author for correspondence
} 
pit. Pruning was performed in the October of 1989, when the cultivars Catuaí and Mundo Novo were 8 and 6 years old, respectively.

The following treatments were evaluated for both cultivars: 1) Control (no pruning); 2) Pruning of the orthotropic branch ('decote') at $2.0 \mathrm{~m}$ on all rows; 3 ) 'Decote' at $1.5 \mathrm{~m}$ on all rows; 4) 'Decote' at $1.5 \mathrm{~m}$ on alternate rows; 5) Pruning of the plagiotropic branches ('esqueletamento') of the upper half of the plant on all rows; 6) 'Esqueletamento' of the upper half of the plant on alternate rows; 7) 'Esqueletamento' of the entire plant on all rows; 8) 'Esqueletamento' of the entire plant on alternate rows; 9) 'Esqueletamento' of one side of the entire plant on all rows; 10) Pruning of the orthotropic branch ('recepa') at $0.80 \mathrm{~m}$ on all rows; 11) 'Recepa' at $0.80 \mathrm{~m}$ on alternate rows. The experimental design was randomized blocks, with four replications. For the cultivar Catuaí, each experimental unit had 24 planting pits $\left(120 \mathrm{~m}^{2}\right)$, with the 16 central plants used for evaluation $\left(80 \mathrm{~m}^{2}\right)$. For the cultivar Mundo Novo, the experimental units had 36 planting pits $\left(180 \mathrm{~m}^{2}\right)$, with the 24 central plants used for evaluation $\left(120 \mathrm{~m}^{2}\right)$.

Damages caused by frosts were visually scored by three independent individuals and the percentage of leaves and branches affected on each plant was obtained, according to methodology described by Caramori et al. (1996). These data were transformed to arcsin $\sqrt{\% / 100}$, and the Tukey test at 0.05 was applied to separate the means. A regression equation was fitted to the data to explain frost damage according to pruning height.

\section{RESULTS AND DISCUSSION}

During the experimental period, two frosts occurred in the site, one on July 29, 1990, and the other on June 26, 1994. The first was a typical radiation frost of moderate intensity, with minimum screen temperature of $1.2{ }^{\circ} \mathrm{C}$ recorded on a weather station located at $200 \mathrm{~m}$ from the experiment. The second was considered a severe frost, with minimum screen temperature of $-1.0{ }^{\circ} \mathrm{C}$ and cold winds of strong intensity causing severe damages to the main coffee areas in Brazil.

Damages caused by the frost of 1990 on both cultivars Catuaí and Mundo Novo are presented in Figures 1 and 2, respectively.

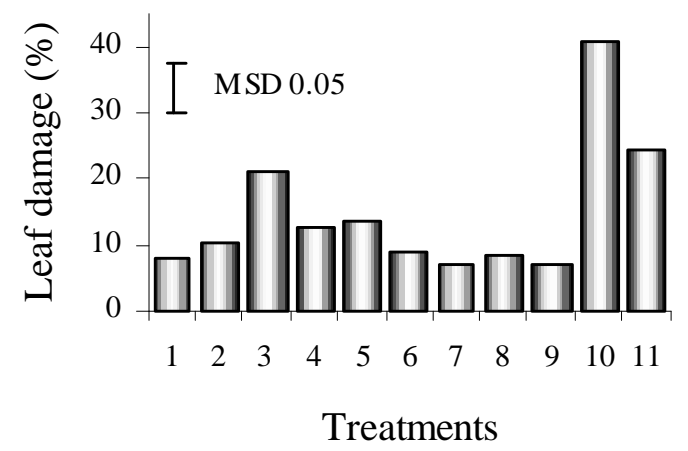

Figure 1. Frost damage on coffee plants of the cultivar Catuaí submitted to different types of pruning.

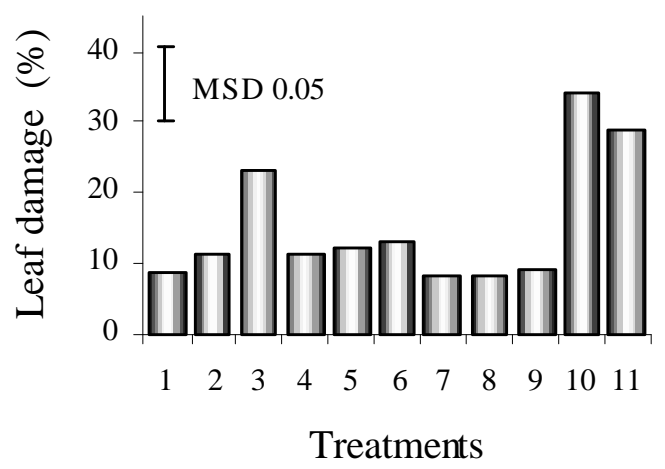

Figure 2. Frost damage on coffee plants of the cultivar Mundo Novo submitted to different types of pruning.

In general, the cultivars Catuaí and Mundo Novo showed similar frost damages under different pruning types (Figs. 1 and 2).

The coffee plants submitted to 'recepa' at 0.80 $\mathrm{m}$ suffered intensive leaf and branch damages. In the other treatments, only leaf damages were observed. The increment of damage level was caused by the reduction of height due to the pruning system, which exposed the plants to lower temperature within the inversion layer, and also contributed to reduce self protection provided by the crown. 
The treatments with the pruning type 'esqueletamento' had lower leaf damage, similar to the coffee plants without pruning. Lower damages on the coffee plants submitted to this type of pruning were due to the lower diameter of the crown of the coffee plants. This characteristic allows the penetration of solar radiation within the canopy during the day, contributing to keep the soil warmer. During the night the soil heat is transferred to the surface, warming up the air near the coffee plants. The smaller crown diameter of the coffee plants submitted to 'esqueletamento' is due to the pruning of the plagiotropic branches at the average distance of $20-30 \mathrm{~cm}$ from the trunk (orthotropic branch).

The pruning systems on alternate rows resulted on less damage compared to the same type of pruning on all rows, but the reduction did not occur on the same proportion of the amount of pruned plants.

Based on data from treatments with pruning at different heights, a regression equation was fitted to explain frost damage according to the height of pruning. Results indicated that frost damage has a significant inverse correlation with pruning height. Best fit was obtained with an exponential equation (Figs. 3 and 4).

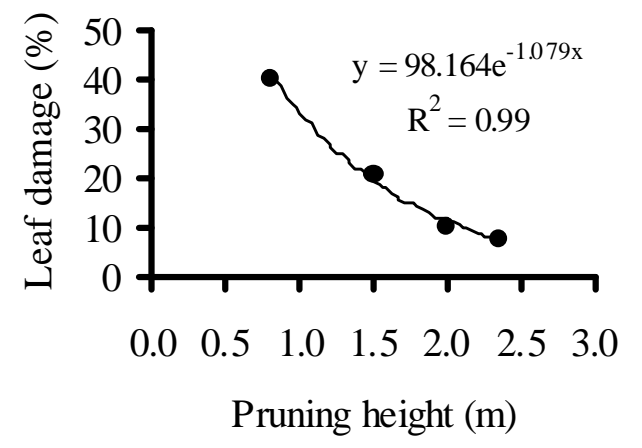

Figure 3. Percentage of leaf damage by frost as a function of pruning height for the coffee cultivar Catuaí.

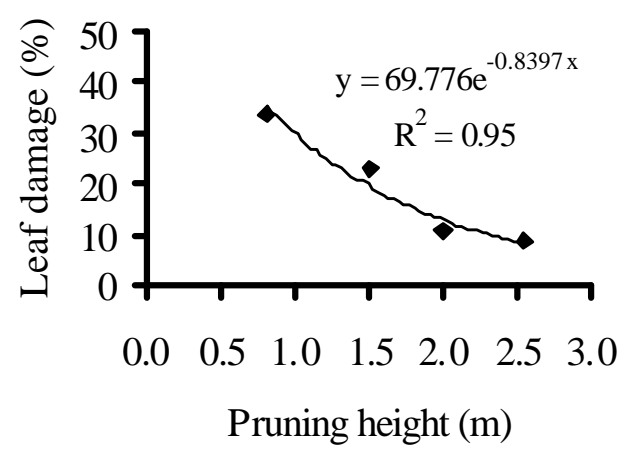

Figure 4. Leaf damage by frost as a function of pruning height for the coffee cultivar Mundo Novo.

After the frost of 1994, due to its strong intensity, all coffee plants were severely injured on leaves, branches and part of the trunks, independent of pruning type. Trunks remained undamaged only up to $0.80 \mathrm{~m}$ above ground. All coffee plants were cut at $0,60 \mathrm{~m}$ height and recovered completely.

The results obtained in this experiment indicated that damages caused by frost could be intensified due to type and height of pruning. The prunings of the type 'esqueletamento' and those at higher levels on the plant are more suitable for the management of the coffee crop in regions with frost risk. Prunings at lower plant level, such as 'recepa', should be applied only to a small fraction of the plantation each year, to minimize the risk of loss in case the frost occurs in the following winter.

It could be, thus, conclude that the contribution of pruning as a routine management practice in the coffee production system depends upon its adaptation to the regional frequency and intensity of frost.

\section{RESUMO}

Foram avaliados os danos causados pelas geadas ocorridas em 1990 e 1994 em cafeeiros de duas cultivares de Coffea arabica L., Catuaí e Mundo Novo, conduzidos em Londrina-PR. Os tipos e sistemas de podas aplicados foram $o$ esqueletamento a $20-30 \mathrm{~cm}$ do tronco, decote a $1,5 \mathrm{~m}$ e $2,0 \mathrm{~m}$ de altura e recepa a $0,80 \mathrm{~m}$ de 
altura. As podas foram feitas em área total e em linhas alternadas e em diferentes partes da planta. Os dados obtidos indicaram que os danos por geada podem ser intensificados em função do tipo e altura da poda. A poda do tipo esqueletamento e as podas altas são mais indicadas para o manejo das lavouras nas regiões mais sujeitas ao fenômeno de geada. No caso de geada severa, todos os cafeeiros foram afetados, independente do tipo de poda.

\section{REFERENCES}

Androcioli Filho, A.; Siqueira, R.; Caramori, P.H.; Pavan, M.A.; Sera, T. \& Soderholm, P.K. (1986), Frost injury and performance of Coffee at $23^{\circ} \mathrm{S}$ in Brasil. Experimental Agriculture, 22, 71-74

Camargo, A.P. \& Salati, E. (1967), Determinación de la temperatura letal para hojas de café en heladas. Café (Lima) 8, 1215

Chaves, J.C.D. \& Manetti Filho, J.(1990), Danos de geada em cafeeiros submetidos à adubação potássica e calagem. Paper presented at $16^{\text {th }}$ Congresso Brasileiro de Pesquisas Cafeeiras,.6 - 9 November, Espírito Santo do Pinhal, São Paulo

Caramori, P.H. \& Sera, T. (1978), Avaliação de danos provocados por geada em diferentes espaçamentos e cultivares. Paper presented at $6^{\text {th }}$ Congresso Brasileiro de Pesquisas Cafeeiras, 24 - 27 October, Ribeirão Preto, São Paulo

Caramori, P.H. \& Sera, T. (1979), Influência do porte do cafeeiro no dano provocado por geada. Paper presented at $7^{\text {th }}$ Congresso
Brasileiro de Pesquisas Cafeeiras, Araxá, Minas Gerais

Caramori, P.H. \& Manetti Filho, J. (1993), Proteção dos cafeeiros contra geadas. IAPAR, Londrina

Caramori, P. H.; Androcioli Filho, A.; Leal, A. C. (1996), Coffee shade with Mimosa scrabella Benth. for frost protection in southern Brazil. Agroforestry systems, 33, 205-214

Faria, R.T. de \& Caramori, P.H. (1986).

Caracterização físico-hídrica de um latossolo roxo distrófico do município de Londrina, PR. Pesquisa Agropecuária Brasileira, 21, 1303-1311

Instituto Agronômico do Paraná, Londrina, PR. (1991), Modelo tecnológico para o café no Paraná. IAPAR, Londrina

Manetti Filho, J.; Caramori, P.H. \& Sereia, V.J. (1984), Efeito da geada nas cultivares Mundo Novo e Catuaí. Paper presented at $11^{\text {th }}$ Congresso Brasileiro de Pesquisas Cafeeiras, $22-25$ October, Londrina, Paraná

Manetti Filho, J. \& Caramori, P.H. (1986), Desenvolvimento de uma câmara para simulação de temperaturas baixas. Pesquisa Agropecuária Brasileira, 21, 1005-1008

Siqueira, R.; Androcioli Filho, A.; Pavan, M.A. \& Chaves, J.C.D. (1983), Densidade de plantio, poda dos primeiros ramos e produção de duas cultivares. Pesquisa Agropecuária Brasileira, 18, 763-769

Received: March 09, 1999; Revised: March 19, 1999; Accepted: July 23, 1999. 